\title{
Special Strategic Plan Model for Special Economic Zone to Support Tourist Destination Special Region of Yogyakarta (Descriptive Study of the Potential of Special Economic Zones in Yogyakarta)
}

\author{
Bambang Jatmiko ${ }^{1}$, Suryo Pratolo ${ }^{2}$, Misbahul Anwar ${ }^{3}$, Kholifah Fil Ardhi ${ }^{4}$ \\ \{bambang_jatmiko65@yahoo.com¹, suryopratolo@gmail.com², misbahulanwar@yahoo.com ${ }^{3}$, \\ kfardhi@yahoo.com ${ }^{4}$ \} \\ Universitas Muhammadiyah, Yogyakarta, Indonesia ${ }^{1-4}$
}

\begin{abstract}
The purpose of this study is to make a Strategic Plan for Special Economic Zones to support the Yogyakarta Special Region Tourism Destination. The ease of Direct Investment Construction (KLIK) Piyungan is predicted to grow the value of DIY investment by $10-15 \%$. The existence of KLIK is also considered effective to exceed the DIY investment target, which is set at Rp1.5 trillion. The prediction of KLIK's contribution to DIY investment growth of 10 to $15 \%$ is a minimum. The research method uses a qualitative descriptive method, with secondary data sources. The data was also carried out by the FGD (Forum Group Disksusi) by inviting relevant agencies and experts. The population is the entire Special Economic Zone that has been determined, namely: Piyungan, Bantul, Kulonprogo, and Yogyakarta City. Based on Governor Regulation Number 99, the Year 2016, Article 6 has the task of DIY to implement Appropriate Technology Development.
\end{abstract}

Keywords: Models, strategic plans, special economic zones (sez), competitiveness, tourism destinations.

\section{Introduction}

According to Law 39/2009, zoning regulations are provisions governing spatial use requirements and control provisions and are drawn up for each designation zone, which is carried out with detailed plans. According to Law 39/2009 article 3, that zoning aspects in the Special Economic Zones (SEZ) can be classified into 7 (seven) zones, namely: (a). Export processing; (b). Logistics; (c). Industry; (d). Technology development; (e). Tourism; (f). Energy; (g). Another economy. In all its forms, SEZs are a logical consequence of an era where many countries implement growth policies directed through exports. However, based on neoclassical economic theory, SEZ is still considered the second-best policy, although it is preferred because of its protective policies, SEZ requires subsidies as a form of benefits and incentives offered to companies, industries, and investors [1]. According to the World Bank, SEZs in all its forms consist, at least, areas that are geographically bounded by separate customs areas, are governed by a regulatory body, and the benefits can be felt by those located within the area [2]. The reason for implementing this policy is that SEZs can create 
competitive industries in a country. This industry can then expand and vary. The formation of special economic zones can be through the cooperation of outsiders who come from different territories [3]. SEZ can also be applied as a location to conduct new policy experiments that are free market if successful, they can be used as a reference for policies in other regions. SEZ is often used as a tool to encourage employment activities. Many of the SEZs are directed to attract labor-intensive industries. SEZs also encourage employment through increased demand for infrastructure (creating vacancies in the engineering and construction sectors), services (such as restaurants and transportation), and local utilities (such as water and electricity), however, the impact on labor is more significant in small countries with a population of less than five million [2]. SEZ also contributes to the development of human resources / HR [4]. SEZ is an area where domestic companies interact with foreign companies; the formation of SEZ allows domestic companies to learn a lot from foreign companies. SEZ can be formed for various reasons. The potential of SEZs requires the formulation of strategies for program success. Strategy formulation is used to determine the SEZ competitiveness of a regional area [5].

According to the Ministry of Industry data, as of 2012, there were at least 96 Industrial Estates spread across Indonesia. The Industrial Estate Association recorded 65 members of Industrial Estates until 2014. Of these, Industrial Estates are more concentrated on Java (72\%). Until 2012, the automotive sector still dominated business activities in Industrial Estates in Indonesia, especially in Java, with $54.8 \%$. In addition to automotive, several sectors that support the business activities of Industrial Estates in Indonesia are the steel industry (9.5\%), logistics $(4.8 \%)$, the building materials industry $(4.9 \%)$, and the food and beverage industry (4.2\%). The Special Region of Yogyakarta has also established the Piyungan industrial area in Bantul, which has been officially launched as the location for the implementation of the Direct Investment Construction Facility (KLIK). KLIK Piyungan is predicted to grow the value of DIY investment by $10-15 \%$. The existence of KLIK is also considered effective to exceed the DIY investment target, which is set at Rp1.5 trillion. Head of the DIY One-Stop Integrated Licensing Services (PTSP) Office Suyata revealed the predicted contribution of KLIK to the growth of DIY investment of 10 to $15 \%$ is a minimum. The investment climate must be improved to succeed in the SEZ [4]. That number is not final, because it will still be calculated further. After counting, it is estimated that the target will be even higher. "KLIK will clearly encourage investment growth. There, one area with only one hectare, if the calculations with one or two companies enter with an investment of all over Rp. 15 billion, that's not up to 5,000 square meters. Just multiply by KLIK Piyungan, which covers 335 hectares], "Suyata explained in the Kepatihan Complex on Tuesday (3/13/2018). Suyata explained, in 2018, the target of the realization of DIY investment would be Rp1.5 trillion, an increase compared to the previous year, which was Rp1.2 trillion. It is expected that with the Piikungan KLIK, investment flows into DIY can grow more rapidly (source: https://www.jogja.co/kawasanindustri-335-hekt-dil launched-Jogja-target-rp15-trillion-in invested/) while Kulonprogo is prepared to become the center of the steel and metal industry and requires infrastructure investment of Rp 11.58 trillion. The funds are needed to build ports and power plants. "At present, PT Jogja Magasa Iron is said to have committed an investment of Rp 5.4 trillion to build an integrated steel plant in Kulonprogo. The formation of SEZ is expected to be able to balance development, but if strategic issues are not resolved, it will create unequal development [6] The objectives of this study are as follows: "To Make Strategic Plans for Special Economic Zones to Support Yogyakarta Special Region Tourism Destinations". 


\section{Literature Review}

\subsection{Strategic Planning}

Strategic Planning (Strategic Planning) is a management tool used to manage current conditions to project future conditions, so the strategic plan is a guide that organizations can use from current conditions for them to work towards the next 5 to 10 years [7]. This means that the meaning that a leader must have dreams have ideals both short-term, medium-term or long-term to achieve what is expected. To achieve a strategy that has been set by the organization in order to have a competitive advantage, the company leaders, operations managers must work within a system that is in the process of strategic planning / strategic planning [8]. A good organizational system, a leader, should also be able to apply the principles of good and right management, starting Plan, Do, Check and Action. The ability to plan for manufacturing companies must be used appropriately so that it can become a superior weapon in strategic planning [9]. To achieve a strategy set by the organization in order to have a competitive advantage, company leaders, operations managers must work within a system that is in the strategic planning process [8]. The ability of a leader to manage a manufacturing company must be used appropriately so that it can become a superior weapon in strategic planning [26]. Strategic planning is explicitly related to change management, this has been the result of research by several experts (e.g., [10-13]. Lorange (1980) wrote that strategic planning is an activity that includes a series of processes from innovation and changing companies so that if strategic planning does not support innovation and change, then it is a failure [12].

The method is often used: Strategic planning is the process carried out by an organization to determine the strategy or direction, and make decisions to allocate its resources (including capital and human resources) to achieve this strategy. Various business analysis techniques can be used in this process, including SWOT analysis (Strengths, Weaknesses, Opportunities, Threats), PEST (Political, Economic, Social, Technological), or STEER (Socio-cultural, Technological, Economic, Ecological, Regulatory).

\subsection{Competitiveness}

According to Porter. et al. (1995) says: "competition is at the core of the success or failure of firms". In any endeavor, competition is the core of a company's success or failure, meaning that the success of a person or company/organization will be seen through the process (input-process-output-outcome). There are two sides to competition, namely success because it encourages companies to be more dynamic and competitive in producing products and providing the best service for their markets, so that competition is seen as a motivating opportunity [14]. While the other side is a failure because it will weaken companies that are static, fear of competition, and unable to produce quality products, so competition is a threat to the company. The dimensions of competitiveness of a company, as stated by Muhardi (2007)[15], by quoting [16] consist of costs (quality), quality (quality), time of delivery (delivery), and flexibility (flexibility) ).

The four dimensions are further explained by Muhardi (2007), complete with the following indicators: a. Cost is a dimension of operational competitiveness that includes four indicators, namely production costs, labor productivity, use of production capacity, and inventory. The element of competitiveness consisting of costs is capital that is absolutely owned by a company which includes financing its production, labor productivity, utilization of 
the company's production capacity and the existence of production reserves (inventory) which can be used at any time by the company to support the smooth running of the company $b$ [15]. Quality, as intended by Muhardi (2007), is a dimension of competitiveness that is also very important, which includes various indicators including product display, product acceptance period, product durability, speed of resolution of consumer complaints, and product conformity to design specifications. Product appearance can be reflected in the design of the product or service; a good product display is one that has a simple design but has high value. The period of receipt of the product is intended by the length of age the product can be accepted by the market, the longer the life of the product on the market shows the quality of the product is getting better. The durability of the product can be measured from the economic age of product use. University of North Sumatra c. Delivery time is a dimension of competitiveness that includes various indicators, including the timeliness of production, reduction of production waiting time, and the timeliness of product delivery. The three indicators are related, the timeliness of product delivery can be influenced by the timeliness of production, and the length of time the product is waiting. d. Flexibility is a dimension of operational competitiveness that includes various indicators, including the types of products produced, speed of adjusting to environmental interests [15].

The factors that affect competitiveness are:

a. Location Paying attention to the business location is very important for the convenience of buyers and is a major factor for business continuity. A strategic business location will attract the attention of buyers. According to [17]: the location or location will be very important to meet the convenience of customers in visiting; consumers will certainly look for the shortest mileage. Although it does not rule out the possibility of consumers from a distance will also buy, but the percentage is small.

b. Price According to [18], Price is the sum of all values exchanged by consumers for the benefits of owning or using the product or service. Price determines whether a supermarket, minimarket, or supermarket is visited by consumers or not. The price factor also influences a buyer to take the University of North Sumatra decision. Prices are also related to discounts, gift-giving coupons, and sales policies. Price is the value of an item or service measured by an amount of money. In order to get an item or service that they want, a consumer must be willing to pay a sum of money. For customers who are sensitive, usually low prices are an important source of satisfaction because they will get high value for money [19].

c. Services Service programs are often the first point of view of a supermarket/minimarket manager. Service through products means consumers are fully served through the supply of existing products, quality products. Services through physical capabilities, refer to the convenience of equipment (trolley or shopping basket), convenient parking, good lighting, as well as hospitality from employees.

d. Quality or quality Confidence to win the market competition will be largely determined by the quality of the products produced by the company. With regard to product quality, [15] in his book Operations Strategies for Competitive Advantage cites the opinion, Adam, and Ebert, stating: "product quality is the appropriateness of design specifications to function and use as well as the degree to which the product conforms to the design specifications" [20]. Product quality is indicated by the suitability of the design specifications with the function or use of the product itself, and also the suitability of the product with the design specifications. So a company has competitiveness if the company produces quality products in the sense that they are in accordance with market needs. 


\subsection{Destination}

According to Daryanto (1997), in the Indonesian dictionary, Destination is defined as a place or tourist destination. The tourist destination (DTW) is a place where all tourism activities can be carried out with the availability of all tourist facilities and attractions for tourists. The elements of tourism destinations include [21]:

a. Object and tourist attraction

b. Facility

c. Infrastructure

d. Environment

Meanwhile, according to Yoeti (1996), Tourist Destination Areas include [22]:
a. Something to see
b. Something to do
c. Something to buy
d. Something to enjoy
e. Something to memorable

\subsection{Special Economic Zone (SEZ)}

Special Economic Zones (SEZ) are areas with certain boundaries covered in regions or regions to carry out economic functions and obtain certain facilities. SEZ was developed through the preparation of areas that have geo-economic and geostrategic advantages and serve to accommodate industrial, export, import, and other economic activities that have high economic value and international competitiveness. Basically, SEZs are formed to create a conducive environment for investment, export, and trade activities to encourage economic growth and as a catalyst for economic reform. This idea was inspired by the success of several countries that first adopted it, such as China and India. Even empirical data illustrates that SEZ in the country is able to attract investors, especially foreign investors, to invest and create jobs. This is due to the ease that investors get, the ease in the form of facilities in the fields of fiscal, taxation and customs. There are even some in the non-fiscal sector, such as bureaucratic facilities, special arrangements in the field of labor and immigration, as well as efficient services and order in the region. In order to accelerate the achievement of national economic development, it is necessary to increase investment through the preparation of areas that have economic and geostrategic advantages. The area is prepared to maximize industrial activities, exports, imports, and other economic activities that have high economic value. SEZ development aims to accelerate regional development and as a breakthrough model for regional development for economic growth, including industry, tourism, and trade so as to increase employment. The Development of Special Economic Zones is directed to provide an optimal contribution in achieving the 4 (four) national priority agendas set out in Nawacita, namely:

a. Build Indonesia from the periphery by strengthening regions and villages within the framework of a unitary state;

b. Improve the quality of life of Indonesian people;

c. Increase people's productivity and competitiveness in international markets;

d. Achieve economic independence by moving the strategic sectors of the domestic economy. The target of Developing Special Economic Zones 
a. Increase investment through the preparation of areas that have geo-economic and geostrategic advantages;

b. Optimization of industrial activities, exports, imports, and other economic activities that have high economic value;

c. Accelerating regional development through the development of new centers of economic growth for the balance of development between regions; and

d. Realizing a breakthrough model of regional development for economic growth, including industry, tourism and trade so as to create jobs.

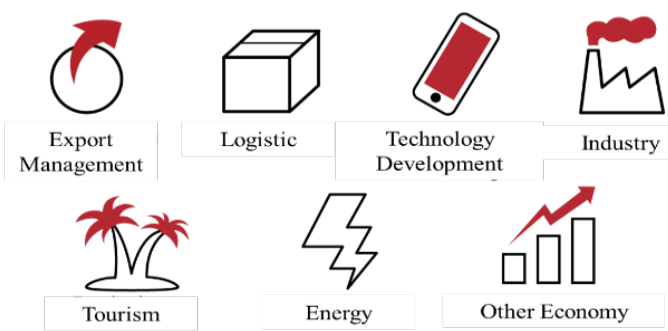

Fig. 1. Special Economic Zones Consist of One Or Several Zones

\section{Research Methodology}

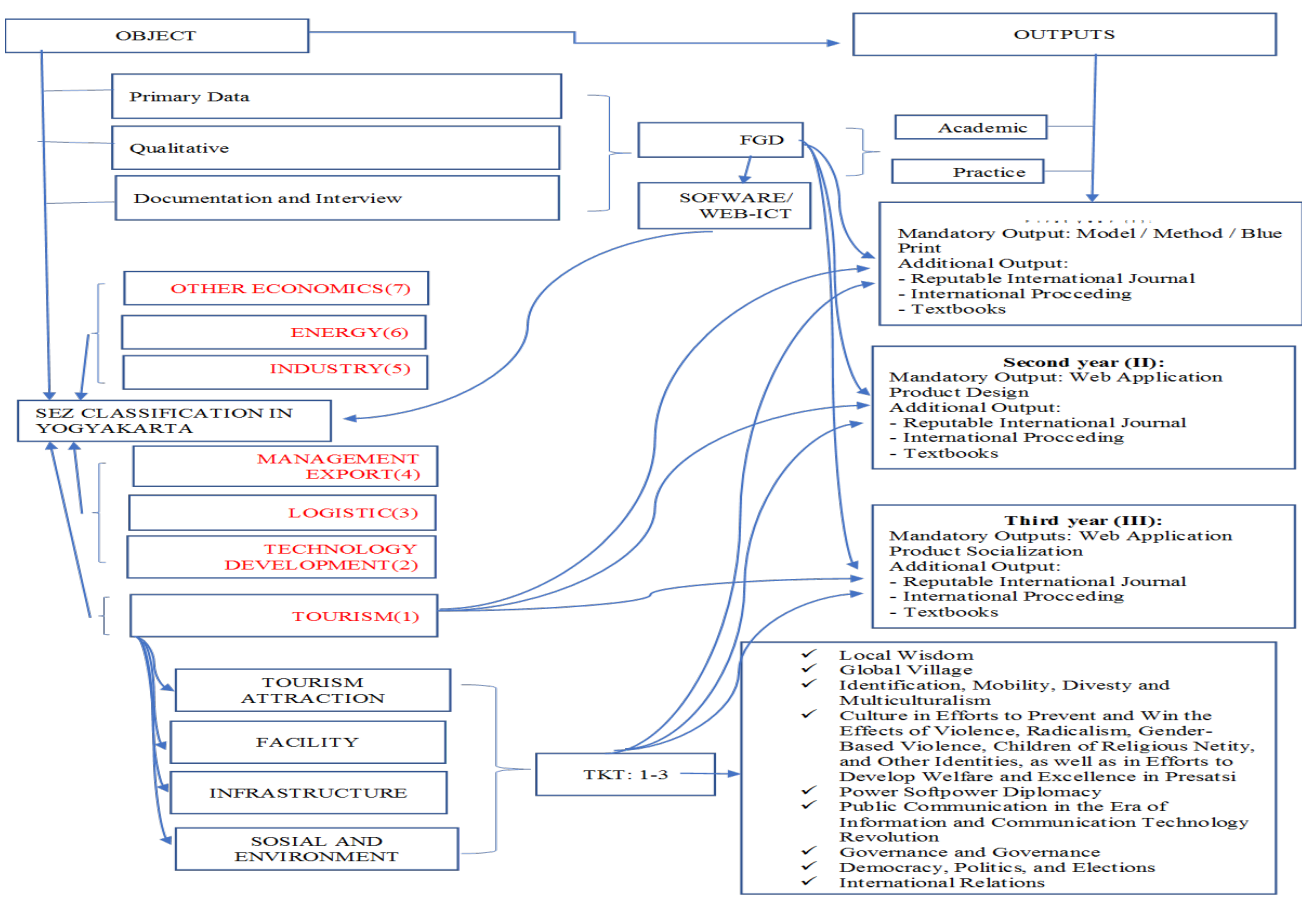

Fig. 2. Research Flow 


\section{Results and Discussion}

Research on Special Economic Zones is still very little carried out by researchers in Indonesia. The researcher tries to discuss the Strategic Plan of Special Economic Zones to support the Yogyakarta Special Region Tourism Destination. In principle, the SEZ Yogyakarta is still in the stage of mapping and designing Special Economic Zones. The research object of this research focuses on the following aspects: (1) aspects of the regulatory framework, in which researchers coherence of the regulatory framework related to the development of SEZs in Yogyakarta in the perspective of regional autonomy and decentralization, (2) institutional aspects, related to cooperation and roles played by institutions involved in the development and management of SEZs, both government and private, in Yogyakarta (3) aspects of development in SEZs, which include funding and infrastructure development in the area and access to the area, in Yogyakarta (4) aspects of SEZing, which is related to policies regarding fiscal and non-fiscal incentives offered to businesses in the region, and (5) lessons that can be drawn from the experience of developing SEZs in Yogyakarta.

\subsection{Technology Problems in Yogyakarta}

The Centre for Appropriate Technology Development is a technical advisory agency in the field of Engineering Technology under the auspices of the Department of Industry and Trade DIY. Based on Governor Regulation Number 99 the Year 2016 Article 6, the task of the Centre for Appropriate Technology Development is to Implement Appropriate Technology Development. To realize this, the appropriate Technology Development Centre has the following functions: (a). Compilation of work programs for the Centre for Appropriate Technology Development; (b). To carry out research, development, and application of appropriate technology; (c). The dissemination of research results, development, and application of appropriate technology; (d). Facilitation of utilizing the results of research, development, and application of appropriate technology; (e). implementation of production and service of appropriate technology tools; (f). implementation of marketing of appropriate technology tools; (g). implementation of collaborative development of appropriate technology; (h). Implementation of administration; (i). Carry out monitoring, evaluation and compilation of appropriate Technology Development Centre program reports; (j). Performing other tasks.

\subsection{Logistical Issues to Support SEZ in Yogyakarta}

Train is one of the modes of transportation that is seen to be effective and efficient in the process of shipping goods. Delivery of goods via the freight train is an option for freight managers to provide logistical services to consumers by utilizing the multiple available modes. To support it all, PT Kereta Api Indonesia in the business of shipping goods, it is necessary to make a strategy that will support the business plan of shipping goods. Therefore there needs to be a mapping of the business development strategy of shipping goods via railroad. In this process, PT Kereta Api Indonesia should also include its business plans in other BUMN and private companies as logistical business stakeholders in Indonesia. There are five strategies for developing the business of shipping goods by train that can be developed by PT Kereta Api Indonesia, including:

a) Prepare railroad infrastructure 
PT Kereta Api Indonesia must map out future business plans in any area in Indonesia that will become a freight forwarding service area. This also includes plans to expand the market with the construction of new railroad tracks or the addition of double track railroads. This infrastructure development plan must also be widely publicized to the Indonesian people or to logistical stakeholders in Indonesia, including infrastructure support facilities and connectivity. Mapping infrastructure development is, of course, also taking into account the factors of economic growth in Indonesia and development plans in Indonesia as a whole.

b) Increasing the capacity of freight train cars

The second strategy is to provide additional capacity through increasing the number of freight cars, increasing the number of freight cars that can be pulled in one trip and also increase the volume of goods that can be transported in each car. In addition, PT Kereta Api Indonesia must also pay attention to variations in the type of freight cars in accordance with the goods transported. For example, for agricultural or fishery products, refrigerated carriages can be provided.

c) Preparing warehouse facilities/storage of goods

The third strategy is by preparing warehouse storage facilities. For train stops with freight cars, PT Kereta Api Indonesia must prepare warehouse or storage facilities. This is in line with the logistics process in general that requires temporary storage for goods that will be redistributed with other modes of transportation or become a liaison/hub to be forwarded to the destination of the goods delivery. Besides, this warehouse can also be used as temporary storage of goods for those who need a freight train service. These warehouse facilities can be in the station area or close to the station so that the process of loading and unloading of goods can also be facilitated. For the provision of warehouse facilities, PT Kereta Api Indonesia can provide these facilities on its own or partner with the private sector in the form of joint operations.

d) Preparing facilities and infrastructure for the process of loading and unloading goods

In addition to warehouses, PT Kereta Api Indonesia as the manager of freight trains, must also prepare advice and targets for the loading and unloading process. For example, the provision of cranes for containers or the provision of loading docks that facilitate the process of loading and unloading of goods. The character of trains that have a tight schedule on the trip must also be considered. This means that in the process of loading and unloading it must also have a loading and unloading time standard; thus the facilities and infrastructure provided must also consider the time standard.

e) Prepare connectivity to support the process of shipping goods by the door to door

The fifth strategy is to prepare connectivity for the door to door delivery process. This connectivity can be provided by PT Kereta Api Own through other business units or other subsidiaries and can also be done in collaboration with other state-owned companies or private parties that also run the logistics business. Connectivity is provided in the form of supporting transport modes such as trucks of various sizes that are tailored to the needs of transportation. In addition, PT Kereta Api Indonesia must also open the widest possible cooperation with Indonesian logistics stakeholders to further strengthen and expand the market for freight shipments via railroad.

\subsection{SEZ Policy to Support Yogyakarta Tourism}

Jogja is one of the tourist destinations that is visited by tourists from many tourist attractions in Indonesia. Tourists visiting Jogja are not only tourists who are in Jogja but tourists from other regions in Indonesia and even foreign tourists. The age of tourists visiting 
Jogja varies both children, adolescents, and even parents. Tourists who come to Jogja are not just traveling, but some also come to study, research, and even do business. Due to the large number of tourists visiting Jogja so that it has a positive impact on the progress of tourism in Jogja as it is today. Behind the progress of tourism in Jogja, of course, there are supporting factors. What are the factors that support the advancement of tourism in Jogja? then we will give the following answer:

(1). Community Factors: (a). Improvement and maintenance of tourist facilities so that they are comfortable and safe for tourists to visit, such as the use of the Merapi eruption area for lava tour attractions; (b). Exploring tourist attractions in Jogja either through the mouth to mouth or through social media; (c). Often holds cultural events and events related to tourism in Jogja; (d). Establishment of tourism care communities in several tourist attractions in Jogja to explore tourist attractions, make repairs and maintenance of tourist facilities; (e). Community initiatives to open tourism support services such as vehicle rental services in Yogyakarta as an effort to facilitate public transportation that still does not reach tourist attractions in Jogja; (2). Government Policy Factors: (a). Improving facilities and improving tourist attractions in Yogyakarta; (b). Facilitating access to tourist attractions, including opening new highways, repairing roads, and stocking public transportation; (c). Disseminating information to the people of Jogja about the importance of tourism; (d). Promoting tourism in Yogyakarta both to the people of the province of Yogyakarta and the people of Indonesia and even internationally through events, research, education, and training related to tourism.

\subsection{SEZ Policy to Encourage Exports}

a. The export value of goods from D.I. Yogyakarta sent through several ports in Indonesia in August 2016 amounted to US \$ 25.426.097 an increase of 50.27 percent compared to the previous month with a value of US $\$ 16.920 .622$. Compared to a year ago, cumulative from January to August, the value of exports fell by 1.76 percent.

b. The three main export destinations for goods in August 2016 were the United States, Germany, and Japan, each at 35.96 percent; 9.72 percent; and 6.34 percent.

c. The development of the largest export value in August 2016 against July 2016 amounted to 227.69 percent aimed at India. The largest cumulative development of January August 2016 against January - August 2015 (cumm. Y-o-y) with an increase of 30.09 percent was aimed at the country of France.

d. The export value of goods from D.I. Yogyakarta to the ASEAN region amounting to US $\$ 1.295,478$. This value rose 38.17 percent compared to a month ago. The three main export destination countries in the ASEAN region are Singapore, Malaysia and Thailand, each at 43.60 percent; 22.86 percent; and 14.70 percent.

e. Non-knitwear (HS 62), Furniture, home lighting (HS 94), and leather goods (HS 42), were the three main commodity groups with the highest export values in August 2016 each at 36.69 percent. ; 12.56 percent and 7.90 percent.

f. The biggest commodity development from July 2016 to August 2016 was the Headgear commodity (HS 65), which increased by 140.23 percent. The biggest developments from January - August 2015 to January - August 2016 (cumm. Y-o-y) were Paper / Cardboard commodities (HS 48) with an increase of 550.88 percent.

g. Exports of goods from D.I. Yogyakarta in August 2016 amounted to 65.42 percent sent via the Tanjung Emas loading port, Central Java Province.

h. Imported D.I goods. Yogyakarta in August 2016 through Adi Sutjipto airport with a value of US \$ 448.315, an increase of 70.19 percent compared to July 2016. If compared 
to a year ago, cumulatively from January to August experienced an increase of 201.83 percent.

i. Most of D.I's imports. Yogyakarta in August 2016 originated from Hong Kong with a value of US \$161.578, equivalent to 36.04 percent of all recorded import values.

j. $\quad$ The main import commodities are special woven fabrics (HS 58) valued at US \$ 117.848 or 26.29 percent of total imports.

\subsection{SEZ Policy to Support the Industry}

Products such as crafts, fashion, animation, and games (games) in the two industrial regions, are directed to penetrate the export market by applying the principle of "fair trade" or fair trade. "The fair trade starting from raw materials in the form of wood must not come from protected forests, but industrial forests," The production process in the industrial area which is designed to implement the Direct Investment Construction Facility or "KLIK" program, he said, will certainly involve the local community. "There must be a connection with the surrounding community, such as making handicraft products. Cutting wood can be in industrial areas, but can arrange it in their respective homes," he said again.

\subsection{SEZ Policy to Support Energy}

Yogyakarta has many locations that are pioneers in the use of renewable energy. Lime Fruit Market, for example, since five years ago, has been using rotten fruit waste into electrical energy with technology adopted from Sweden. In recent years, the Pantai Baru area in the south has also been built by the Bayu Power Plant to meet the needs of ice factories for fishermen. The central government also established Baron Technopark in Gunungkidul Regency, as a research center on the use of renewable energy, where research into the use of wind and solar as a source of power generation continues. Not long ago, the local government completed and formalized the utilization of solar energy in an effort to address the water needs of Gunungkidul residents. This technology is called the Solar Water Pump System (SPATS).

One of the great potentials that can be directly utilized in Indonesia is solar/solar power plants. This facility can be installed on the roofs of people's homes, and Indonesia has abundant potential. However, as a new technology, its use does require greater efforts. "We consider all the potential. Sustainability must also be considered, including its social impact. Technology must not enter the community but with "coercion". So, the social side is also included in this program, as well as educating the public.

Renewable energy (renewable energy) which is traded by Germany and the United States. In the process of utilizing renewable energy, said Ahmad, the role of the government is very dominant. A clear legal umbrella and a supportive policy are needed. A clear legal basis can be the basis for implementing the policy. For example, whether the government will provide subsidies for people who use renewable energy sources, how to apply the tariffs and what awards will be given. The good news, the DIY government and local people's representatives have just made a breakthrough. Currently, DIY is in the process of drafting a Regional Regulation (Raperda) on Renewable Energy and is claimed to be the first in Indonesia. If it has been passed, this regulation will become the legal basis for the use of renewable energy, and become an example for other regions in Indonesia. Local governments will also be encouraged to come up with policies that support their development in the field. 
The regional regulation will also map the constraints on the use of renewable energy, how the government's role in financing this sector, including the management of existing resources.

\subsection{Other Economics}

One of the leading tourism attractions in the city of Yogyakarta is shopping tourism spread across several regions, one of which is the largest traditional market in the city of Yogyakarta, Beringharjo. Shopping tourism is strongly supported by the role of the creative industries in Yogyakarta, and if not coupled to be an important part of tourism, the potential for shopping tourism will not be optimal.

"That's just one example; there are still many sectors of the creative economy and creative industries that play a role in the development of tourism such as fashion, crafts and many other things," In the development of the creative economy or the creative industries, the Tourism Office has a duty to promote the potential of the creative economy, while the process of fostering and developing becomes the realm of other agencies namely the Industry and Trade Office and the Office of Manpower and Transmigration SME Cooperatives.

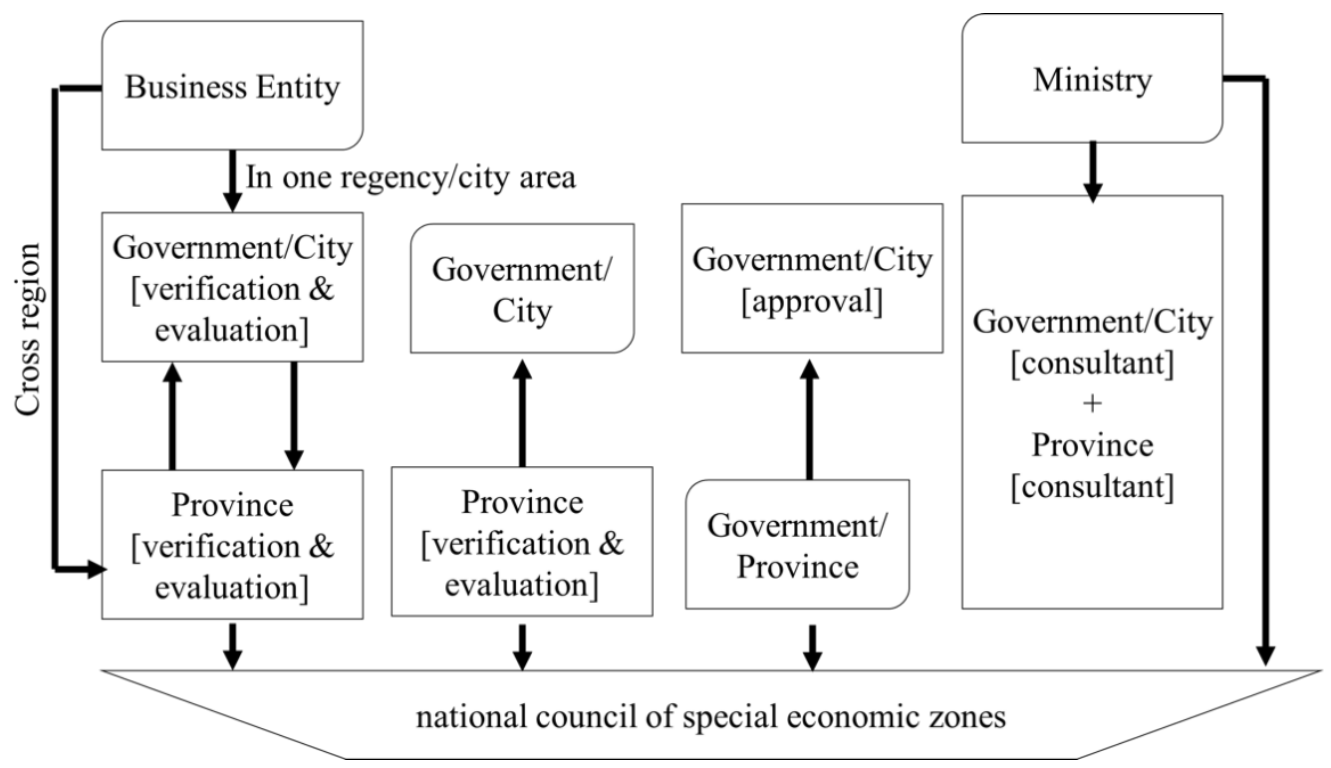

Fig. 3. Competitiveness of Yogyakarta Special Region Tourism Destinations

Table 1. Document Requirement

\begin{tabular}{|c|c|c|c|c|c|}
\hline No & Documents & $\begin{array}{l}\text { Business } \\
\text { Entity }\end{array}$ & $\begin{array}{c}\text { Local } \\
\text { Government } \\
\text { Entity }\end{array}$ & $\begin{array}{c}\text { Province } \\
\text { Government }\end{array}$ & Ministry \\
\hline 1 & Application Form & $\sqrt{ }$ & $\sqrt{ }$ & $\sqrt{ }$ & $\sqrt{ }$ \\
\hline 2 & $\begin{array}{l}\text { Power of Attorney (if the proposer } \\
\text { is a consortium) }\end{array}$ & $\sqrt{ }$ & - & - & - \\
\hline 3 & $\begin{array}{l}\text { Deed of the establishment of } \\
\text { business entity }\end{array}$ & $\sqrt{ }$ & - & - & - \\
\hline 4 & Financial profiles of the last 3 & $\sqrt{ }$ & - & - & - \\
\hline
\end{tabular}


years that have been audited

5 Approval from the district / city government related to the proposed SEZ location

6 A statement of ownership of the value of equity (at least $30 \%$ of the value of the investment)

7 Description of the SEZ development plan

8 Detailed map of the development location and proposed area of SEZ

9 SEZ location allotment plan that is equipped with zoning regulations

10 Economic and financial feasibility studies

11 Plans and sources of financing

12 Environmental Impact Analysis

13 The proposed duration for the operation of the SEZ and the strategic plan for the development of the SEZ

14 Location permit/location determination for proof of land rights

15 Statement of ability to carry out the construction and management of the SEZ

16 Statement of ability to carry out the construction and management of the SEZ

17 District or city government commitment related to the plan for providing incentives and facilities

Source: developed by researchers [23].

\section{Conclusion}

Base on the discussion, the researcher can conclude the following:

1. The Centre for Appropriate Technology Development for DIY, has the following functions: (a). Compilation of work programs for the Centre for Appropriate Technology Development; (b). To carry out research, development and application of appropriate technology; (c). The dissemination of research results, development and application of appropriate technology; (d). Facilitation of utilizing the results of research, development and application of appropriate technology; (e). implementation of production and service of appropriate technology tools; (f). implementation of marketing of appropriate technology tools; (g). implementation of collaborative development of appropriate technology; (h). Implementation of administration; (i). Carry out monitoring, evaluation and compilation of appropriate Technology Development Centre program reports; (j). Other tasks. 
2. Delivery of goods via the freight train is an option for the shipping manager to provide logistical services to consumers by utilizing the multiple available modes. To support it all, PT Kereta Api Indonesia in the business of shipping goods, it is necessary to make a strategy that will support the business plan of shipping goods.

3. The factors that support the advancement of tourism in Jogja are as follows: (1). Community Factors: (a). Improvement and maintenance of tourist facilities so that they are comfortable and safe for tourists to visit, such as the use of the Merapi eruption area for lava tour attractions; (b). Exploring tourist attractions in Jogja either through the mouth to mouth or through social media; (c). Often holds cultural events and events related to tourism in Jogja; (d). Establishment of tourism care communities in several tourist attractions in Jogja to explore tourist attractions, make repairs and maintenance of tourist facilities; (e). Community initiatives to open tourism support services such as vehicle rental services in Yogyakarta as an effort to facilitate public transportation that still does not reach tourist attractions in Jogja; (2). Government Policy Factors: (a). Improving facilities and improving tourist attractions in Yogyakarta; (b). Facilitating access to tourist attractions, including opening new highways, repairing roads and stocking public transportation; (c). They are disseminating information to the people of Jogja about the importance of tourism; (d). Promoting tourism in Yogyakarta both to the people of the province of Yogyakarta and the people of Indonesia and even internationally through events, research, education, and training related to tourism.

4. Export value of goods from D.I. Yogyakarta sent through several ports in Indonesia in August 2016 amounted to US $\$ 25,426,097$, an increase of 50.27 percent compared to the previous month with a value of US $\$ 16,920,622$. Compared to a year ago, cumulative from January to August, the value of exports fell by 1.76 percent.

5. Products such as crafts, fashion, animation, and games in the two industrial zones, are directed to penetrate the export market by applying the principle of "fair trade" or fair trade.

6. Yogyakarta has many locations that are pioneers in the use of renewable energy.

7. Shopping tourism is strongly supported by the role of creative industries in Yogyakarta and if not coupled to be an important part of tourism, the potential for shopping tourism will not be optimal.

\section{References}

[1] Cling,J.P. \& Letilly, G.: ExportProcessing Zones: A Threatened Instrument for Global Economy Insertion? Working Paper DT 2001-17. Paris Development et Insertion International (DIAL): Paris (2001)

[2] Akinci, G. \& Crittle, J.: Special Economic Zones: Performance, Lessons Learned, and Implications for Zone Development, Foreign Investment Advisory Service (FIAS). Occasional Paper. World Bank: Washington, D.C (2008)

[3] Bra“Utigam, Deborah, Xiaoyang, Tang: African Shenzhen.: China's Special Economic Zones in Africa”. J. of Modern African Studies (2011)

[4] Aggarwal, A.: Impact of Special Economic Zones on Employment, Poverty, and Human Development. Working paper No. 194 Indian Council for Research on International Economic Relations (ICRIER), New Delhi (2007)

[5] Sarbjit, Singh.: SWOT Analysis of Special Economic Zone. Journal of Accounting - Business \& Management (2017)

[6] Litwack, John M., Qian, Yingyi: Balanced or Unbalanced Development.: Special Economic Zones as Catalysts for Transition. Journal of Comparative Economics (1998) 
[7] Kerzner, H.: Project Management; Systems Approach to Planning, Scheduling and Controlling. John Wesley and Sons, New York (2001)

[8] Brown, Paul.. The evolving role of strategic management development. Journal of Management Development (2005)

[9] Skinner, Wickham.: Manufacturing: Missing Link in Corporate Strategy, Harvard Business Review (1969)

[10] Ansoff, H.L.: Corporate Strategy. McGraw-Hill, New York (1965)

[11] Anthony, R.: Planning and Control Systems: A Framework for Analysis. Division of Research, Graduate School of Business Administration, Harvard University, Boston (1965)

[12] Lorange, Peter.: Corporate Planning - An Executive Viewpoint, Prentice-Hall (1980)

[13] Steiner, George A.: Strategic Planning, Simon and Schuster (1979)

[14] Porter, Michael E., and Claas van der Linde.: "Toward a New Conception of the EnvironmentCompetitiveness Relationship." Journal of Economic Perspectives. Vol. 9, No. 4: 97-118 (1995)

[15] Muhardi.: Strategi Operasi untuk Keunggulan Bersaing, Gahara Pustaka: Yogyakarta (2007)

[16] Ward, R.J., McCreery, J.K., Ritzman, L.P., Sharma, D.: Competitive Priorities in Operations Management, Decision Sciences. Vol. 29: 1037-1048 (1998)

[17] Frans, Royan.: Kiat Sukses Mengelola Supermarket Toko Tradisional Minimarket, Effhar: Semarang (2003)

[18] Sunarto.: Prinsip-prinsip Pemasaran, Edisi ke-2, AMUS, UST Press: Yogyakarta (2004)

[19] Irawan, Handi.: Membedah Strategi Kepuasan Pelanggan, Cetakan Pertama, PT. Gramedia: Jakarta (2008)

[20] Adam, Latif.: Perkembangan Kawasan Ekonomi Khusus (SEZ): Kasus di Beberapa Negara (2007)

[21] Daryanto.: Evaluasi Pendidikan, Rineka Cipta: Jakarta (1997)

[22] Yoeti, A.: Pengantar Ilmu Pariwisata, Angkasa: Bandung (1996)

[23] Ma'ruf, Ahmad.: Tahapan Inisiasi Pembangunan Kawasan Ekonomi Khusus (KEK) Ekonomi Kreatif di Yogyakarta (2018) 